\title{
TINGKAT PARTISIPASI POLITIK DALAM PEMILIHAN GUBERNUR JAWA TENGAH DI KABUPATEN BLORA TAHUN 2018
}

\author{
Ghausthauf Anas Mahendra \\ Mahasiswa Ilmu Pemerintahan \\ Fakultas Ilmu Sosial dan Ilmu politik \\ Universitas Muhammadiyah Yogyakarta \\ ghausthaufanas@gmail.com

\section{Bambang Eka Cahya Widodo} \\ Dosen Ilmu Pemerintahan \\ Fakultas Ilmu Sosial dan Ilmu Politik \\ Universitas Muhammadiyah Yogyakarta \\ bambangeka@umy.ac.id
}

\begin{abstract}
Community political participation in the election of governors and deputy governors is a form of democratic process in a democratic country. The election of the governor and deputy governor in Java was followed by two governor and deputy governor candidates. Candidates for number one are Ganjar Pranowo and Taj Yasin. Then for the second serial number candidates are Sudirman Said and Ida Fauziah. The researcher used qualitative research methods. Data sources presented as authors are primary data and secondary data. Primary data obtained from observations or interviews conducted by the author immediately jumped into the field. Then the following data is secondary data. Secondary data obtained by researchers from the documentation and voter data obtained from Blora Regency KPU and Central Java Provincial Election Commission office. In collecting data, the author uses interview and observation methods. Data analysis is done in several ways, namely by combining data, reducing data, and then drawing conclusions. The results of the study indicate that: the factors that influence participation are differences in the interests of candidates. Then the people did not really know the governor and deputy governor candidates. The next factor is that the social structure of the community at the village level also opposes people's interest in coming to the tps. Community work involving farmers and at the time of the election took place, in Blora district was harvesting so that farmers preferred to harvest their crops. Community political organizations strongly oppose political education because in political, social and other community organizations organizations are supporters of individual or group quality. Community members who are experienced in organization certainly have good political education.
\end{abstract}

Keywords: political participation, gubernatorial election, abstentions 
Partisipasi politik masyarakat dalam pemilihan gubernur dan wakil gubernur adalah salah satu bentuk proses berdemokrasi di sebuah negara demokrasi. Pemilihan gubernur dan wakil gubernur di jawa tengah diikuti oleh dua calon gubernur dan wakil gubernur. Calon nomor urut satu yaitu Ganjar Pranowo dan Taj Yasin. Kemudian untuk calon nomor urut kedua adalah Sudirman Said dan Ida Fauziah. Peneliti menggunakan metode penelitian kualitatif. Sumber data yang dijadiakan sebagai penulis yaitu data primer dan data sekunder. Data primer diperoleh dari pengamatan atau wawancara yang dilakukan penulis langsung terjun ke lapangan. Kemudian data yang berikunya yaitu data sekunder. Data sekunder diperoleh peneliti dari hasil dokumentasi dan data pemilih yang diperoleh dari KPU Kabupaten Blora serta kantor KPU Provinsi jawa Tengah. Dalam pengumpulan data, penulis menggunakan metode wawancara dan observasi. Analisis data dilakukan dengan beberapa cara, yaitu dengan menggabungkan data, reduksi data, dan kemudian menarik kesimpulan. Hasil penelitian menunjukkan bahwa: faktor yang mempengaruhi partisipasi adalah perbedaan kepentingan calon. Kemudian masyarakat tidak begitu mengenal calon gubernur dan wakil gubernur. Faktor berikutnya adalah struktur sosial masyarakat di tingkat pedesaan juga menentang minat masyarakat untuk datang ke tps. Pekerjaan masyarakat yang melibatkan petani dan pada saat pelaksanaan pemilihan berlangsung, di kabupaten blora sedang masa panen sehingga para petani lebih memilih untuk memanen hasil pertanian mereka. Organisasi politik masyarakat sangat menentang pendidikan politik karena dalam organisasi politik, sosial, dan organisasi masyarakat lainnya menjadi pendukung terhadap kualitas individu atau kelompok. Anggota masyarakat yang berpengalaman dalam berorganisai tentu memiliki pendidikan politik yang baik.

\section{Kata kunci: partisipasi politik, pemilihan gubernur, golput}

\section{Pendahuluan}

Partisipasi masyarakat merupakan dasar pelaksanaan demokrasi sesuai dengan cita-cita negara demokrasi yang mengedepankan kesejahteraan rakyat. Sehingga prinsip-prinsip demokrasi dan partisipasi masyarakat merupakan kesatuan penting dalam rangka pembangunan tak terkecuali pembangunan di setiap daerah. Partisipasi politik juga merupakan aspek penting dalam sebuah tatanan negara demokrasi, sekaligus merupakan ciri khas adanya modernisasi politik. Dalam hubungannya dengan demokrasi, partisipasi politik berpengaruh terhadap legitimasi masyarakat terhadap jalannya suatu pemerintahan. Pada suatu pemilu misalnya partisipasi politik berpengaruh terhadap legitimasi masyarakat kepada pasangan calon yang terpilih.

Partisipasi politik rakyat tentu tidak lepas dari kondisi atau sistem politik yang sedang berproses. Sistem kepolitikan bangsa 
Indonesia hingga dewasa ini telah berkali-kali mengalami perubahan, mulai dari orde baru sampai pada reformasi. Disadari bahwa reformasi sering dimaknai sebagai era yang lebih demokratis. Sebagai proses dari transformasi politik, makna pilkada selain merupakan bagian dari penataan struktur kekuasaan agar lebih menjamin berfungsinya mekanisme check and balances di antara lembaga-lembaga politik dari tingkat pusat sampai daerah, masyarakat mengharapkan pula agar pilkada dapat menghasilkan kepala daerah yang akuntabel, berkualitas, legitimate, dan peka terhadap kepentingan masyarakat.

Pada Pemilihan Gubernur Jawa Tengah kali ini, hanya ada dua pasangan yang akan bersaing memperebutkan kursi gubernur dan wakilnya. Dua tokoh yang berkompetisi sebagai calon pemimpin Jawa Tengah bukanlah wajah baru di panggung politik Ganjar Pranowo kembali maju pada Pemilihan Gubernur periode ini. Sebagai calon petahana, Ganjar dipasangkan dengan Taj Yasin Maimun atau Gus Yasin anak dari pengasuh Pondok Pesantren Sarang, Rembang, KH Maimun Zubair. Pasangan Ganjar Yasin maju dengan dukungan PDI Perjuangan, Nasdem, Partai Demokrat, PPP, dan Golkar. Lawannya, Sudirman Said, mantan Menteri ESDM 2014-2016, didampingi Ida Fauziyah yang merupakan anggota DPR dari PKB. Pasangan ini diusung oleh koalisi Gerindra, PKB, PKS, dan PAN.

Tabel 1 : partisipasi pemilih gubernur dan wakil gubernur di kabupaten Blora tahun 2018

\begin{tabular}{|c|c|c|c|c|c|}
\hline \multirow[t]{2}{*}{ NO } & \multirow[t]{2}{*}{ KECAMATAN } & \multirow[t]{2}{*}{ DPT } & \multicolumn{3}{|c|}{$\begin{array}{l}\text { HASIL PUNGUTAN SUARA } \\
\text { 2018) }\end{array}$} \\
\hline & & & PEMILIH & $\begin{array}{l}\text { PROSENTASE } \\
\text { PEMILIH }\end{array}$ & $\begin{array}{l}\text { PROSENTASE } \\
\text { GOLPUT }\end{array}$ \\
\hline 1 & BLORA & 71264 & 47605 & $67 \%$ & $33 \%$ \\
\hline 2 & JEPON & 49004 & 31810 & $65 \%$ & $35 \%$ \\
\hline 3 & BOGOREJO & 20093 & 12848 & $64 \%$ & $36 \%$ \\
\hline 4 & BANJAREJO & 47.670 & 28.112 & $59 \%$ & $41 \%$ \\
\hline 5 & TUNJUNGAN & 36884 & 21940 & $59 \%$ & $41 \%$ \\
\hline
\end{tabular}


374 | Ghausthauf AM, Bambang ECW. Tingkat Partisipasi...

\begin{tabular}{|l|l|r|r|r|r|}
\hline 6 & CEPU & 56868 & 37.692 & $66 \%$ & $34 \%$ \\
\hline 7 & JIKEN & 31.117 & 18.552 & $60 \%$ & $40 \%$ \\
\hline 8 & SAMBONG & 22481 & 14064 & $63 \%$ & $37 \%$ \\
\hline 9 & KEDUNGTUBAN & 45316 & 25681 & $57 \%$ & $43 \%$ \\
\hline 10 & RANDUBLATUNG & 59330 & 38285 & $65 \%$ & $35 \%$ \\
\hline 11 & KRADENAN & 32417 & 20674 & $64 \%$ & $36 \%$ \\
\hline 12 & JATI & 39851 & 27751 & $70 \%$ & $30 \%$ \\
\hline 13 & NGAWEN & 47615 & 28438 & $60 \%$ & $40 \%$ \\
\hline 14 & KUNDURAN & 52185 & 32708 & $63 \%$ & $37 \%$ \\
\hline 15 & TODANAN & 50473 & 30870 & $61 \%$ & $39 \%$ \\
\hline 16 & JAPAH & 28255 & 17162 & $61 \%$ & $39 \%$ \\
\hline JUMLAH & & 690823 & 434192 & $63 \%$ & $37 \%$ \\
\hline
\end{tabular}

Sumber: KPU Blora

Berdasarkan tabel 1, dapat diketahui bahwa jumlah pemilih yang tidak menggunakan hak pilihnya dan memilih untuk golput masih tinggi. Hal ini menunjukkan bahwa antusiasme masyarakat dalam pemilihan umum khususnya pemilihan gubernur dan wakil gubernur cukup rendah.

Tabel 2 : partisipasi pemilih bupati dan wakil bupati Blora tahun 2015

\begin{tabular}{|c|c|c|c|c|c|}
\hline \multirow[t]{2}{*}{ NO } & \multirow[t]{2}{*}{ KECAMATAN } & \multirow[t]{2}{*}{ DPT } & \multicolumn{3}{|c|}{$\begin{array}{llll}\text { HASIL PUNGUTAN } & \text { SUARA } & \text { (PILKADA } \\
2015) & & & \\
\end{array}$} \\
\hline & & & PEMILIH & $\begin{array}{l}\text { PROSENTASE } \\
\text { PEMILIH }\end{array}$ & $\begin{array}{l}\text { PROSENTASE } \\
\text { GOLPUT }\end{array}$ \\
\hline 1 & BLORA & 72.836 & 53.537 & $74 \%$ & $26 \%$ \\
\hline 2 & JEPON & 49.236 & 37.172 & $75 \%$ & $25 \%$ \\
\hline 3 & BOGOREJO & 20.397 & 15.351 & $75 \%$ & $25 \%$ \\
\hline 4 & BANJAREJO & 48.562 & 34.885 & $72 \%$ & $28 \%$ \\
\hline 5 & TUNJUNGAN & 37.125 & 28.026 & $75 \%$ & $25 \%$ \\
\hline 6 & CEPU & 59.424 & 41.224 & $69 \%$ & $31 \%$ \\
\hline 7 & JIKEN & 31.208 & 22.212 & $71 \%$ & $29 \%$ \\
\hline 8 & SAMBONG & 23.965 & 15.801 & $66 \%$ & $34 \%$ \\
\hline 9 & KEDUNGTUBAN & 46.253 & 32.669 & $71 \%$ & $29 \%$ \\
\hline
\end{tabular}




\begin{tabular}{|l|l|l|l|l|l|}
\hline 10 & RANDUBLATUNG & 63.365 & 43.035 & $68 \%$ & $32 \%$ \\
\hline 11 & KRADENAN & 33.274 & 23.432 & $70 \%$ & $30 \%$ \\
\hline 12 & JATI & 41.008 & 28.220 & $69 \%$ & $31 \%$ \\
\hline 13 & NGAWEN & 48.001 & 33.534 & $70 \%$ & $30 \%$ \\
\hline 14 & KUNDURAN & 53.087 & 38.010 & $72 \%$ & $28 \%$ \\
\hline 15 & TODANAN & 51.428 & 37.456 & $73 \%$ & $27 \%$ \\
\hline 16 & JAPAH & 28.335 & 21.044 & $74 \%$ & $26 \%$ \\
\hline JUMLAH & & 706.604 & 505.842 & $72 \%$ & $28 \%$ \\
\hline
\end{tabular}

Sumber: KPU Blora

Dari kedua tabel di atas, angka pemilih pada pemilihan gubernur jauh lebih sedikit dibandingkan pemilih pada pemilihan bupati. Pada pemilihan bupati tahun 2015 silam, masyarakat yang datang ke TPS untuk menggunakan hak pilihnya jauh lebih banyak. Perilaku pemilih dalam kaitannya dengan keikutsertaan negara dalam pemilihan gubernur dan wakil gubernur merupakan serangkaian kegiatan dalam membuat keputusan.

Data dari tabel 1 dan tabel 2 memberikan gambaran bahwa partisipasi masyarakat dalam pemilu masih rendah. Angka golput dalam pemilihan Gubernur dan Wakil Gubernur berdasarkan data yang diperoleh dari KPU Blora mencapai 37\%, dan angka golput pada saat pemilihan kepala daerah dalam hal ini yaitu bupati tingkat pemilih yang golput hanya sebesar $28 \%$. Hal ini tentunya menjadi masalah dalam konteks pemilu karena masyarakat enggan untuk datang ke TPS dan memilih untuk golput. Dari perbandingan data diatas, pemilih pada pemilihan bupati pada tahun 2015 jauh lebih tinggi dibanding dengan pemilihan gubernur. Hal ini menjadi perhatian yang menarik bagi penulis untuk mengetahui penyebab masih banyaknya pemilih yang golput di pilgub tahun 2018.

\section{Tinjauan Pustaka}

\section{a. Pengertian Partisipasi Politik}

Yang dimaksud dengan partisipasi politik menurut Ramlan Surbakti adalah suatu masyarakat yang ikut serta dalam menentukan keputusan 
376 | Ghausthauf AM, Bambang ECW. Tingkat Partisipasi...

yang berkaitan dengan kehidupannya. Menurut Merian Budiarjo, mengungkapkan bahwa partisipasi politik adalah kegiatan yang melibatkan sekelompok orang untuk ikut secara aktif kehidupan berpolitik.

b. Faktor-faktor Partisipasi Politik

1) Modernisasi

Yang dimaksud dengan modernisasi adalah pembaruan di segala bidang yang berbanding lurus dengan kemajuan teknologi dan perkembangan media masssa.

2) Terjadi perubahan struktur kelas sosial

Munculnya kelas kelas baru sebagai akibat dari industrialisasi di kelas menengah dan kelas pekerja dan tidak lepas dari modernisasi.

3) Pengaruh kaum intelektual dan meningkatnya komunikasi di massa modern.

Adanya Ide ide yang baru seperti, liberalisme, yang dapat membangkitkan tuntuntan-tuntutan untuk berpartisipasi dalam pengambilan suara.

4) Adanya konflik diantara pemimpin-pemimpin politik.

Dalam memperebutkan dan mencari massa, pemimpin politik selalu bersaing untuk mencapai suatu kemenangan.

5) adanya keikutserataan pemerintah yang semakin luas dalam unsur ekonomi,sosial dan budaya

Pengaruh dari keputusan yang dibuat oleh pemerintah seringkali menumbuhkan rangsangan dari organisasi sosial dan mereka selalu melakukan tuntutan.

\section{b. Budaya Politik}

Budaya politik menurut Gabriel Almond dan Verba adalah suatu kemampuan yang dimiliki oleh masyarakat yang didalamnya terdapat sikap dan orientasi politik didalam suatu sistem politik. Almond dan Verba membagi budaya politik menjadi 3 komponen: 
1. Komponen Kognitif, yaitu tingkat kemampuan, pemahaman, dan keyakinan terhadap suatu sistem politik, seperti tokoh politik, kebijakan, dan simbol-simbol yang berhubngan dengan sistem politik.

2. Komponen Afektif, yaituterkait dengan perasaan warga negara yang nantinya dapat membuat warga negara tersebut dapat percaya dengan sistem politik tersebut.

3. Komponen Evaluatif, yaitu perasaan yang muncul dari masyarakat terhadap kepuasan objek politik.

Ada beberapa tipologi kebudayaan politik yang bersifat murni, maka dapat dibedakan tiga bentuk kebudayaan politik:

1. Kebudayaan Subyek-Parokiall

Kebudayaann subyek parokial adalah bentuk dari kebudayaan politik yang menjelaskan bahwa masyarakat desa ataupun penduduk di suatu wilayah dan secara turun temurun memilih untuk mengembangkan kesetiaan terhadap sistem politik.

2. Kebudayaan Partisipan-Subyekk

Kebudayaan partisipan-subyek ini merupakan sebuah bentuk peralihan dari kebudayaan yang diangap parokial menuju ke bentuk partisipan.

3. Kebudayaan Parokial-Partisipan

Masalah kontemporer mengenai pembangunan kebudayaan di belahan dunia yang sedang berkembang. Dalam negara yang berkembang, masyarakat lebih banyak memilih untuk menganut budaya parokial yang rata-rata sangat dominan di dalam sebuah negara.

\section{c. Tipologi Budaya Politik}

Ada tiga bentuk tipologi politik yang telah di jelaskan oleh beberapa tokoh, yaitu:

1. Budaya Politik Parokial 
Budaya politik parokial khusus membahas tentang peranan di dalam politik dan partisipasi nya sangat rendah. Hal ini ditandai dengan tidak meningkatnya perkembangan di dalam sistem politik.

2. Budaya Politik Kaula

Budaya politik ini membahas mengenai masyarakat yang sudah memiliki orientasi yang tinggi terhadap sistem politiknya.

3. Budaya Politik Partisipan

Yang dimaksud dengan budaya politik partisipan yaitu masyarakat dianggap aktif dalam kehidupan politik. Masyarakat secara sukarela ikut andil dalam proses demokrasi di dalam suatu negara.

\section{d. Pemilu}

Menurut Jimly Asshiddiqie pemilu merupakan mekanisme penentuan pendapat rakyat melalui sistem yang bersifat langsung. Dasim Budiman Syah mendefinisikan Pemilu sebagai suatu proses di mana para pemilih memilih orang-orang untuk mengisi jabatan-jabatan politik tertentu. Sedangkan Paimin Napitupala memberikan pengertian pemilu adalah sebuah mekanisme politik untuk mengartikulasikan inspirasi dan kepentingan warga negara dalam proses memilih sebagian rakyat menjadi pemimpin pemerintah. Lebih jauh diuraikan oleh beliau bahwa pemilu adalah sebagai suatu sistem dan proses bekerja struktur dan fungsi elemen atau sub sistem elektual laws dan elektual progress menuju terciptanya suatu representative government dan democratize government yang melibatkan berbagai organisasi dan pranata baik dari infra struktur pemerintahan maupun dalam supra struktur pemerintahan, mutlak membutuhkan suatu kemampuan dalam menyelesaikan proses konvensi input menjadi output yang mendatangkan outcome tertentu bagi tercapainya kesejahteraan bagi seluruh masyarakat.

Dedi Mulyadi memberikan pengertian mengenai Pemilu yaitu sebuah mekanisme politik modern untuk menginternalisasikan aspirasi, espektisi dan kepercayaan (truss) masyarakat dalam menentukan dan memilih pemimpinnya di lembaga legislatif maupun eksekutif (pusat dan daerah) secara langsung. 
Adapun fungsi pokok dari Pemilu adalah:

a. Fungsi keterwakilan (representative ness) yaitu di dalam masyarakat terdapat kelompok-kelompok masyarakat yang memiliki perwakilan dan ditinjau dari aspek geografis, fungsional, dan deskripsi wilayah.

b. Fungsi integrasi, yaitu berarti adanya partai yang $m$,enerima partai lain dan masyarakat juga menerima partai tersebut.

c. Fungsi mayoritas, memiliki cakupan yang sangat besar untuk menjamin stabilitas pemerintah dan kemampuannya untuk memerintah (govern ability).

Di lain pihak Pamlian menyatakan ada 4 fungsi dari pemilihan umum yaitu,

a. Pembentukan atau pemupukan kekuatan yang absah,

b. Mencapai tingkat ketaqwaan politik,

c. Pembudayaan politik,

d. Pelembagaan politik.

Di samping ke empat fungsi di atas menurut J. Krisnadi dapat ditambahkan 2 fungsi lagi yaitu: fungsi pengendalian konflik dan pendewasaan politik.

2. Tujuan Pemilihan Umum

Tujuan penyelenggaraan pemilihan umum menurut Arbi Samit adalah: pertama, melaksanakan kedaulatan rakyat yang menjamin kepentingan semua golongan, kedua, menentukan wakil rakyat yang sekaligus harus melayani penguasa dan rakyat secara seimbang, ketiga, membentuk pemerintahan perwakilan lewat OPP pemenang (tunggal atau oposisi), keempat, penggantian atau pengakaran elit penguasa; kelima, pendidikan politik bagi rakyat melalui partisipasi dalam pemilihan umum.

3. Asas Penyelenggaraan Pemilihan Umum

Pemilu dilaksanakan secara efektif dan efisien berdasarkan asas langsung, umum, bebas, rahasia, jujur, dan adil. 


\section{Pelaksanaan Pemilihan Umum}

Pemilihan dilaksanakan oleh komisi pemilihan umum sebanyak lima tahun sekali. Pemilihan ini mencakup banyak hal, diantaranya yaitu dengan perencanaan program dalam proses pemilu itu sendiri. Dalam hal ini kpu dan bawaslu ikut andil secara penuh dalam proses pemilu.

Di dalam negeri pemungutan suara dilaksanakan pada hari libur atau hari yang diliburkan secara nasional. Sedangkan pemungutan suara di luar negeri dapat dilaksanakan bersamaan atau sebelum pemungutan suara pada hari sebagaimana dimaksud di atas.

5. Penyelenggara dan Peserta Pemilihan Umum

Menurut Pasal 6 Undang-undang Nomor 12 Tahun 2008 Pemilu, untuk memilih anggota DPR, DPRD provinsi dan DPRD kabupaten/kota diselenggarakan oleh Komisi Pemilihan Umum (KPU). Dan pengawasan terhadap penyelenggaraan pemilu dilaksanakan oleh Bawaslu.

Adapun peserta Pemilu dapat dikategorikan dalam Pemilu untuk memilih anggota DPR, DPRD provinsi dan DPRD kabupaten/kota serta Pemilu untuk memilih anggota DPD (Dewan Perwakilan Daerah). Pasal 7 Undang-undang Nomor 8 Tahun 2012 mengatur bahwa peserta Pemilu untuk memilih anggota DPR, DPRD provinsi dan DPRD kabupaten/kota adalah Partai Politik. Sedangkan peserta Pemilu untuk memilih anggota DPD diatur dalam Pasal 1 Undang-undang Nomor 8 Tahun 2012 yaitu perseorangan. Persyaratan partai politik untuk menjadi peserta Pemilu diatur dalam Pasal 8 Ayat (1) dan (2) Undang-Undang Nomor 8 Tahun 2012, namun kedua ayat dari pasal 8 ini berdasarkan keputusan Mahkamah Konstitusi Nomor 52/PUU-X/2012 tidak mempunyai kekuatan hukum mengikat lagi. Namun partai politik untuk dapat menjadi peserta Pemilu harus mengajukan pendaftaran kepada KPU.

\section{e. Patronase}

Patronase adlah salah bentuk yang timbul akibat adanya perjanjian politik yang dilakukan oleh beberapa pihak. Dapat dikatakan bahwa ini merupakan pembagian keuntungan antara politisi dan para pegiat kampanye yang dalam proses kampanye calon tersebut mendapatkan 
banyak dukungan dari beberapa pihak, sehingga secara tidak langsung pembagian keuntungan itu harus ada.

\section{f. Klientalisme}

Klientalisme tidak sama dengan patronase, hal ini dikarenakan dalam penertian klientalisme secara harfiah memiliki arti bahwa seseorang tersebut merupakan pengikut yang cukup setia terhadap suatu calon tertentu.

\section{Metode Penelitian}

Dalam penelitian ini penulis akan menggunakan metode penelitian berupa penelitian kualitatif, yang artinya dengan menganalisis tingkat partisipasi politik masyarakat yang kemudian akan diuraikan berdasarkan informasi yang diperoleh dari wawancara.

Dalam penelitian ini, peneliti melakukan risetnya terkait dengan partisipasi masyarakat dalam Pemilihan Gubernur dan Wakil Gubernur Jawa Tengah, yaitu di Kabupaten Blora.

Jenis data yang digunakan penulis dalam penelitian ini ada dua, yaitu data primer dan data sekunder.

1. Data primer

Data primer adalah data yang diperoleh secara langsung yang dilakukan oleh peneliti kepada narasumber atau informan.

2. Data sekunder

Data sekunder adalah data yang diperoleh oleh peneliti melalui data sebelumnya, atau data yang telah dikumpulkan oleh pihak lain yang berkaitan dengan masalah penelitian

\section{Pembahasan}

I. FAKTOR FAKTOR YANG MEMPENGARUHI TINGKAT PARTISIPASI MASYARAKAT KABUPATEN BLORA PADA PEMILIHAN GUBERNUR DAN WAKIL GUBERNUR TAHUN 2018 
382 | Ghausthauf AM, Bambang ECW. Tingkat Partisipasi...

Partisipasi politik merupakan suatu aktivitas tentu dipengaruhi oleh beberapa faktor. Menurut Ramlan Surbakti (1992:140) menyebutkan dua variable penting yang mempengaruhi tinggi rendahnya tingkat partisipasi politik seseorang.

Pertama, aspek kesadaran politik terhadap pemerintah (sistem politik). Yang dimaksud dalam kesadaran politik adalah kesadaran hak dan kewajiban warga negara. Misalnya hak politik, hak ekonomi, hak perlindungan hukum, kewajiban ekonomi, kewajiban sosial dll.

Kedua, menyangkut bagaimana penilaian serta apresiasi terhadap kebijakan pemerintah dan pelaksanaan pemerintahnya. Selain itu ada faktor yang berdiri sendiri. Artinya bahwa rendahnya kedua faktor itu dipengaruhi oleh faktor-faktor lain, seperti status sosial, afiliasi politik orang tua, dan pengalaman beroganisasi.

Tabel 1

\begin{tabular}{|l|l|r|l|l|l|}
\hline no & Kecamatan & $\begin{array}{l}\text { Jumlah } \\
\text { golput } \\
\text { pilkada } \\
2015\end{array}$ & $\begin{array}{l}\text { Prosentase } \\
\text { Golput } \\
\text { pilkada 2015 }\end{array}$ & $\begin{array}{l}\text { Jumlah } \\
\text { golput } \\
\text { pilgub } \\
2018\end{array}$ & $\begin{array}{l}\text { Golput } \\
\text { pilgub } \\
2018\end{array}$ \\
\hline 1 & BLORA & 19.299 & $26 \%$ & 23659 & $33 \%$ \\
\hline 2 & JEPON & 12.064 & $25 \%$ & 17194 & $35 \%$ \\
\hline 3 & BOGOREJO & 5.046 & $25 \%$ & 7245 & $36 \%$ \\
\hline 4 & BANJAREJO & 13.677 & $28 \%$ & 19558 & $41 \%$ \\
\hline
\end{tabular}

Dari penjelasan tabel diatas, berdasarkan data yang diperoleh dari KPU Kabupaten Blora, secara kuantitaif partisipasi masyarakat dalam pemilihan gubernur dan wakil gubernur lebih rendah dibandingkan pemilihan bupati pada tahun 2015. Di kecamatan Blora sendiri, jumlah angka golput pada pilkada sebesar 19.299 dan pada pemilihan gubernur masyarakat yang memilih golput mencapai 23.659 suara. Di kecamatan Jepon, angka golput pilkada tahun 2015 mencapai 12.064 dan pada saat pemilihan gubernur angka golput jauh lebih tinggi yaitu sebanyak 17.194 suara. Kecamatan Bogorejo angka golput pada saat pilkada sebanyak 5.046 suara, dan pada 
saat pilgub angka golput juga masih tinggi yaitu sebesar 7245 suara. Kecamatan banjarejo memiliki perbedaan yang sangat besar dimana pada saat pilkada angka golput sebesar 13.667 dan pada saat pilgub mencapai 19.558.

Tabel 2

\begin{tabular}{|l|l|r|l|l|l|}
\hline no & Kecamatan & $\begin{array}{l}\text { Jumlah } \\
\text { golput } \\
\text { pilkada } \\
2015\end{array}$ & $\begin{array}{l}\text { Prosentase } \\
\text { Golput } \\
\text { pilkada 2015 }\end{array}$ & $\begin{array}{l}\text { Jumlah } \\
\text { golput } \\
\text { pilgub } \\
2018\end{array}$ & $\begin{array}{l}\text { Golput } \\
\text { pilgub } \\
2018\end{array}$ \\
\hline 1 & TUNJUNGAN & 9.099 & $25 \%$ & 14944 & $41 \%$ \\
\hline 2 & CEPU & 18.200 & $31 \%$ & 19176 & $34 \%$ \\
\hline 3 & JIKEN & 8.996 & $29 \%$ & 12565 & $40 \%$ \\
\hline 4 & SAMBONG & 8.164 & $34 \%$ & 8417 & $37 \%$ \\
\hline
\end{tabular}

Perbandingan jumlah suara yang tidak digunakan di kecamatan tunjungan pada saat pilkada dan pilgub sangat signifikan. Pada saat pilkada angka golput mencapai 9.099 suara dan pada saat pilkada mencapai 14.944 suara. Di kecamatan cepu, jumlah suara yang golput pada saat pilkada yaitu sebesar 18.200 dan pada saat pilgub sebesar 19.176 suara. Di kecamatan jiken juga terdapat selisih yang cukup banyak, yaitu pada saat pilkada berjumlah 8.996 suara sedangkan pada saat pilgub mencapai 12.565 suara. Di kecamatan sambong jumlah pemilih yang memilih untuk golput tidak begitu besar, taitu 8164 suara pada saat pilkada dan 8417 suara pada saat pilgub.

Tabel 3

\begin{tabular}{|l|l|l|l|l|l|}
\hline no & Kecamatan & $\begin{array}{l}\text { Jumlah } \\
\text { golput } \\
\text { pilkada } \\
2015\end{array}$ & $\begin{array}{l}\text { Prosentase } \\
\text { Golput } \\
\text { pilkada } \\
2015\end{array}$ & $\begin{array}{l}\text { Jumlah } \\
\text { golput } \\
\text { pilgub } \\
2018\end{array}$ & $\begin{array}{l}\text { Golput } \\
\text { pilgub } \\
2018\end{array}$ \\
\hline 1 & KEDUNGTUBAN & 13.584 & $29 \%$ & 19635 & $43 \%$ \\
\hline 2 & RANDUBLATUNG & 20.330 & $32 \%$ & 21045 & $35 \%$ \\
\hline 3 & KRADENAN & 9.842 & $30 \%$ & 11743 & $36 \%$ \\
\hline 4 & JATI & 12.788 & $31 \%$ & 12100 & $30 \%$ \\
\hline
\end{tabular}

Dalam pemilihan bupati dan wakil bupati, angka golput di kecamatan kedungtuban sebesar 13.584 suara dan pada saat pilgub mencapai 19.635. 
384 | Ghausthauf AM, Bambang ECW. Tingkat Partisipasi...

kemudian kecamatan randublatung jumlah suara yang tidak dicoblos saat pilkada sebesar 20.330 dan jumlah golput pada saat pilgub mencapai 21045 suara. Untuk kecamatan kradenan juga tidak jauh berbeda dengan kecamatan lain, golput pada saat pilkada yaitu sebesar 9.842 suara dan pada saat pilgub mencapai 11.743 suara. Akan tetapi di kecamatan jati ada sedikit hal yang berbeda, dimana jumlah golput saat pilgub tahun 2018 lebih kecil dibandingkan dengan pilkada tahun 2015.

Tabel 4

\begin{tabular}{|l|l|l|l|l|l|}
\hline no & Kecamatan & $\begin{array}{l}\text { Jumlah } \\
\text { golput } \\
\text { pilkada } \\
2015\end{array}$ & $\begin{array}{l}\text { Prosentase } \\
\text { Golput } \\
\text { pilkada 2015 }\end{array}$ & $\begin{array}{l}\text { Jumlah } \\
\text { golput } \\
\text { pilgub } \\
2018\end{array}$ & $\begin{array}{l}\text { Golput } \\
\text { pilgub } \\
2018\end{array}$ \\
\hline 1 & NGAWEN & 14.467 & $30 \%$ & 19177 & $40 \%$ \\
\hline 2 & KUNDURAN & 15.077 & $28 \%$ & 19477 & $37 \%$ \\
\hline 3 & TODANAN & 13.972 & $27 \%$ & 19603 & $39 \%$ \\
\hline 4 & JAPAH & 7.291 & $26 \%$ & 11093 & $39 \%$ \\
\hline
\end{tabular}

Partisipasi masyarakat dalam pemilihan bupati dan wakil bupati di Kecamatan Ngawen masih lebih baik jika dibandingkan dengan pemilihan gubernur di tahun 2018. Dimana pada saat pilkada angka golput sebesar 14.467 dan pada pilgub mencapai 19.117 suara. Kecamatan Kunduran juga tidak jauh berbeda dengan kecamatan lainnya, yaitu pemilih yang memilih golput pada pemilihan gubernur dan wakil gubernur lebih besar dibandingkan dengan pemilihan bupati dan wakil bupati. Jumlah pemilih di Kecamatan Todanan pada saat pemilihan bupati juga jauh lebih besar jika dibandingkan dengan pemilih di pemilihan gubernur jawa tengah tahun 2018. Kemudian untuk kecamatan japah, terdapat jarak yang begitu besar antara jumlah pemilih yang golput, dimana pemilih yang golput di pemilihan gubernur jauh lebih besar yakni sebesar 11.093 suara.

Pemilu demi pemilu yang dilaksanakan untuk memilih pemimpin yang nantinya diharapkan untuk dapat merubah kehidupan agar menjadi lebih baik. Begitu pula dengan pemilihan gubernur, masyarakat sangat mengharap adnya perubahan dalam kehidupan berbangsa dan bernegara. Salah satunya yaitu dengan ikut memilih seorang pemimpin dengan cara pemilihan umum. 
Ghausthauf AM, Bambang ECW. Tingkat Partisipasi... | 385

Dari penjelasan yang dikemukakan oleh ketua KPU Kabupaten Kabupaten Blora, Muhammad Hamdun, bahwasanya banyaknya pekerja yang asalnya dari blora kemudian merantau dan tidak kembali ke kampung halaman untuk melakukan pencoblosan. Masyarakat lebih memilih untuk bekerja untuk memenuhi kebutuhan sehari-hari ketimbang datang ke tps. Masyarakat yang penulis wawancara juga menuturkan bahwa banyak saudara dari responden yang keluar kota untuk bekerja dan tidak kembali, dan ratarata orang yang merantau akan pulang pada saat hari raya idul fitri atau idul adha.

Pelaksanaan pemilihan gubernur jawa tengah menurut beberapa responden juga tidak tepat. Hal ini terjadi karena di daerah kecamatan Kradenan dan kecamatan Kedungtuban pada bulan Juni tahun 2018 sedang dalam masa panen raya dan masyarakat tidak datang ke tps dan lebih memilih pergi ke sawah untuk memanen hasil pertanian mereka. Kemudian banyak juga yang mengemukakan bahwa masyarakat tidak mengenal calon gubernur maupun calon wakil gubernur. Responden juga menuturkan bahwa dari pilgub ke pilgub yang dirasakan juga sama saja, tidak ada perubahan yang berarti bagi kehidupan masyarakat.

Pendidikan politik masyarakat juga masih tergolong cukup rendah, karena masyarakat blora sebagian besar bekerja sebagai petani. Dalam hal ini, KPU sebagai lembaga yang secara langsung bergerak sebagai penyelenggara pemilu berkewajiban untuk melakukan pendidikan politik.

Keikutsertaan dan pengalaman masyarakat di pedesaan dalam berorganisasi juga menjadi salah satu faktor yang mempengaruhi partisipasi masyarakat dalam pencoblosan pemilihan gubernur dan wakil gubernur pada tahun 2018. Orang yang berpengalaman dalam organisasi kemasyarakatan, keagamaan, hingga politik pasti memiliki kesadaran bahwa suara mereka sangat berguna untuk melakukan perubahan di masa yang akan datang. Apabila masyarakat sudah memiliki kesadaran bahwa satu suara mereka sangat berguna untuk proses demokrasi dan dapat melakukan perubahan, maka sistem demokrasi di indonesia akan berjalan dengan baik dan uang yang dikeluarkan pemerintah untuk melakukan pemilu tidak terbuang dengan percuma. 


\section{FAKTOR YANG MEMPENGARUHI PANDANGAN TERHADAP OBYEK POLITIK PADA PEMILIHAN GUBERNUR DAN WAKIL GUBERNUR}

Komponen Kognitif, yaitu kemampuan yang menyangkut tingkat pengetahuan dan pemahaman serta kepercayaan dan keyakinan seorang atau masyarakat terhadap jalannya sistem politik dan atributnya, seperti tokohtokoh pemerintahan, kebijaksanaan yang mereka ambil, atau mengenai simbol-simbol yang dimiliki oleh sistem politiknya, seperti ibukota negara, lambang negara, kepala negara, batas-batas negara, mata uang yang dipakai, dan lain sebagainya.

Dalam konteks ini, masyarakat yang memiliki pendidikan yang baik dan terbiasa dalam organisasi, lebih cenderung untuk dapat menggunakan hak pilihnya dengan bijak. Meskipun pemilu bukan merupakan pemilu yang wajib, melainkan pemilu hak setiap individu, akan tetapi apabila seseorang aatau anggota masyarakat yang memiliki pengalaman yang lebih, maka ia akan memanfaatkannya dengan sebaik mungkin. Dalam proses pemungutan suara seperti pada pemilihan gubernur ini, satu suara pun sangat berarti untuk melkukan perubahan, baik itu perubahan yang secara langsung dapat dirasakan oleh masyarakat, maupun yang tidak langsung dapat dirasakan oleh masyarakat.

Komponen Afektif, yaitu menyangkut perasaan seorang warga negara terhadap sistem politik dan peranan yang dapat membuatnya menerima atau menolak sistem politik itu.

Percaturan politik di indonesia mulai dari zaman refolusi, reformasi, hingga orde baru banyak meninggalkan cerita yang mungkin banyak dirasakan oleh warga negara Indonesia. Pemilu demi pemilu yang dilaksanakan untuk memilih pemimpin yang nantinya diharapkan untuk dapat merubah kehidupan agar menjadi lebih baik. Begitu pula dengan pemilihan gubernur, masyarakat sangat mengharap adnya perubahan dalam kehidupan berbangsa dan bernegara. Salah satunya yaitu dengan ikut memilih seorang pemimpin dengan cara pemilihan umum. Dengan ikut memilih, otomatis masyarakat ikut andil dalam melakukan perubahan dan secara tidak langsung ikut dalam proses pembangunan.

\section{FAKTOR YANG MEMPENGARUHI PEMILIHAN UMUM.}


Menurut Jimly Asshiddiqie pemilu merupakan mekanisme penentuan pendapat rakyat melalui sistem yang bersifat langsung. Dasim Budiman Syah mendefinisikan Pemilu sebagai suatu proses di mana para pemilih memilih orang-orang untuk mengisi jabatan-jabatan politik tertentu. Sedangkan Paimin Napitupala memberikan pengertian pemilu adalah sebuah mekanisme politik untuk mengartikulasikan inspirasi dan kepentingan warga negara dalam proses memilih sebagian rakyat menjadi pemimpin pemerintah. Lebih jauh diuraikan oleh beliau bahwa pemilu adalah sebagai suatu sistem dan proses bekerja struktur dan fungsi elemen atau sub sistem elektual laws dan elektual progress menuju terciptanya suatu representative government dan democratize government yang melibatkan berbagai organisasi dan pranata baik dari infra struktur pemerintahan maupun dalam supra struktur pemerintahan, mutlak membutuhkan suatu kemampuan dalam menyelesaikan proses konvensi input menjadi output yang mendatangkan outcome tertentu bagi tercapainya kesejahteraan bagi seluruh masyarakat.

Dari pendapat yang dijabarkan oleh ketua KPU, dari proses sosialisasi kpu sudah melakukannya dengan baik. Kemudian penulis melakukan wawancara dengan masyarakat terkait dengan sosialisai yang telah dilakukan oleh KPU, PPK, maupun PPS. PPK merupakan lembaga yang menyelenggarakan pemilihan di tingkat kecamatan, dan kinerjanya diawasi oleh panwascam, kemudian PPS merupakan lembaga yang melakukan tugas untuk melakukan pemilihan di tingkat desa. Tidak hanya melakukan proses pemilihan, akan tetapi PPK dan PPS juga ikut andil dalam proses sosialisasi.

Kemudian penulis melakukan wawancara dengan warga di kecamatan Tunjungan, para responden berpendapat bahwa benar PPK dan PPS sudah melakukan sosialisai di wilayah mereka masing-masing. Sosalisasi yang dilakukan PPS menyasar anggota masyarakat yang sedang melakukan kegiatan seperti arisan ibu-ibu PKK, ataupun pengajian yang dilakukan oleh bapak-bapak.

Di setiap kecamatan, hiburan dan bentuk sosialisasi yang di lakukan oleh KPU juga beragam. Untuk daerah Cepu, dalam rangka sosialisasi yang bertujuan untuk menjaring partisipasi masyarakat untuk datang ke TPS yaitu dengan diadakannya pentas wayang kulit semalam suntuk. Dalam wayangan ini, sosialisasi diadakan langsung oleh KPU Provinsi Jawa Tengah. Untuk 
388 | Ghausthauf AM, Bambang ECW. Tingkat Partisipasi...

kecamatan Kradenan, sosialisasi dilakukan dengan cara hiburan rakyat berupa orgen tunggal. Sosialisasi ini dilaksanakan oleh PPK kecamatan Kradenan dan diadakan di depan kantor kecamatan Kradenan.

\section{FAKTOR YANG MEMPENGARUHI HUBUNGAN TIMBAL BALIK POLITIK}

Patronase adalah sebuah pembagian keuntungan di antara politisi untuk mendistribusikan sesuatu secara individual kepada pemilih, para pekerja atau pegiat kampanye, dalam rangka mendapatkan dukungan politik dari mereka.

Isu money politik memang selalu menjadi hal sangat menarik saat menjelang dan setelah terjadinya pemilihan umum, pilkada, pileg, maupun pilgub. Masyarakat masih beranggapan bahwa yang memberikan uang maka itulah yang bersungguh sungguh untuk menjadi kepala di pemerintahan. Padahal yang terjadi sebenarnya apabila calon memberikan uang, maka tanggung jawab calon yang terpilih nantinya sudah selesai, karena suara mereka sudah dibeli oleh calon tersebut.

Pada saat penulis melakukan penelitian dan terjun di lapangan, penulis menemukan banyak asumsi bahwa masyarakat akan memilih jika mereka diberikan uang. Sosialisasi dari KPU, Parpol, dan media massa lainnya seperti tidak ada gunanya apabila suara masyarakat masih ditentukan oleh money politik. Kesadaran politik masyarakat harus secara sadar terbentuk dari diri pribadi masing-masing dan harus memiliki tanggung jawab sendiri terhadap suara yang diberikan kepada pasangan calon gubernur dan wakil gubernur.

Dikutip dari Tempo.co, pada hari senin tanggal 19 Februari 2018, calon gubernur Sudirman Said melakukan lawatan ke Kecamatan Cepu untuk melakukan proses kampanye. Dalam kampanye nya, Sudirman lebih memilih untuk bertemu dengan petani dan sedikit menyinggung soal kartu tani. Kemudian, pada tanggal 04 April, calon gubernur Ganjar Pranowo juga melakukan laawatannya ke kabupatennya, lebih tepatnya di kecamatan Blora. Dalam lawatannya, Ganjar lebih berfokus pada pedagang tumpah di pasar blora dan petani tembakau. Dari kunjungan kedua calon gubernur tersebut, di kecamatan cepu angka pemilih cukup besar mencapai $66 \%$, dan di kecamatan 
Blora mencapai 67\%. Dengan kata lain, dengan kedatangan calon gubernur, para masyarakat lebih antusian untuk datang dan berpartisipasi dibandingkan dengan daerah yang tidak di datangi oleh calon gubernur.

Golput bisa dilihat dari berbagai segi karena cakupanya yang cukup luas, Pertama golput teknis yakni mereka yang karena sebab sebab teknis tertentu menjadi golput. Misalnya karena sakit parah dan tidak bisa memilih. Kedua, golput teknis politis yakni golput karena kesalahan teknis dari KPU atau diri sendiri. Ketiga, Golput politis yakni mereka yang merasa tidak mempunyai pilihan dari kandidat yang tersediaatau tidak percaya bahwa pemilu aan membawa perubahan atau perbaikan. Keempat, golput ideologis yakni mereka yang tidak percaya pada mekanisme demokrasi dan tidak mau terlibat didalamnya entah karena alasan fundamentalisme agama maupun alasan politi ideologislainya.

alasan orang untuk memilih golput:

1. Alasan teknis administrative, yaitu seseorang memutuskan tidak ikut memilih karena tidak ada waktu untuk memilih atau berhalangan hadir pada saat pemilihan, seperti harus bekerja di hari pemilihan, sedang ada keperluan, harus ke luar kota di saat hari pemilihan dan sebagainya. Bisa juga karena malas pergi ke TPS dan keliru atau salah dalam proses pencoblosan sehingga suaranya tidak sah.

Terkait dengan masalah administratif, yang lebih cocok untuk dijadikan alasan untuk tidak datang ke TPS adalah banyaknya msyarakat yang merantau ke daerah lain sehingga tidak dapat pulang ke kampung halaman dan tidak dapat juga untuk mencoblos ke TPS.

2. Faktor teknis-politis, seseorang yang terganjal sistem pendaftaran (registrasi) pemilih dan atau tidak terdaftar sebagai pemilih karena kesalahan penyelenggaraan. Karena untuk bisa memilih, umumnya calon pemilih harus terdaftar sebagai pemilih terlebih dahulu. Sistem pendaftaran yang rumit dan tidak teratur mengurangi minat orang dalam pemilihan.

Dalam kasus ini, untuk DPT secara keseluruhan sudah baik. Melalui rekap data yang dilakukan mulai dari tingkat PPS sampai tingkat KPU Kabupaten Blora sudah tidak ada masalah. Hal ini diperjelas oleh hasil 
390 | Ghausthauf AM, Bambang ECW. Tingkat Partisipasi...

wawancara yang peneliti lakukan dengan ketua KPU dan anggota PPK kecamatan Tunjungan.

\section{FAKTOR YANG MEMPENGARUHI RELASI POLITIK}

"Dalam Pilgub tahun 2018, tingkat apatisme masyarakat selalu tinggi, pemilu ke pemilu, masyarakat melontarkan tidak ada perubahan sehingga masyarakat tdk mau datang ke tps sehingga ini menjadi hambatan dalam pilgub" wawancara oleh Pak Hamdun, ketua KPU Blora.

Dalam hubungannya dalam relasi politik, masyarakat lebih menginginkan adanya perubahan dalam kehidupan berbangsa dan bernegara. Basis suara masyarakat berada pada lingkungan terendah, seperti RT dan RW, sehingga calon gubernur dan wakil gubernur tidak dapat menjangkau secara langsung para masyarakat, sehingga relasi secara langsung tidak dapat terjalin. Yang ditunggu oleh masyarakat hanyalah janji politik yang harus dilakukan memalui visi dan misi gubernur yang telah terpilih.

\section{Kesimpulan Dan Saran}

\section{KESIMPULAN}

Dari uraian penjelasan diatas, maka disimpulkan bahwa : faktor yang mempengaruhi partisipasi politik yaitu perbedaan kepentingan calon. Kemudian masyarakat tidak begitu mengenal calon gubernur dan wakil gubernur. Faktor berikutnya yaitu struktur sosial masyarakat khususnya di tingkat pedesaan juga berpengaruh terhadap minat masyarakat untuk datang ke tps. Pekerjaan masyarakat yang mayoritas sebagai petani dan pada saat pelaksanaan pemilihan berlangsung, di kabupaten blora sedang masa panen sehingga para petani mayoritas lebih memilih untuk memanen hasil pertanian mereka. Organisasi politik masyarakat sangat berpengaruh terhadap pendidikan politik karena dalam organisasi politik, sosial, dan organisasi masyarakat lainnya tentu menjadi pendukung terhadap kualitas individu maupun kelompok. Anggota masyarakat yang berpengalaman dalam berorganisai tentu memiliki pendidikan politik yang baik. 
Pendidikan politik masyarakat khususnya di pedesaan sangat rendah, sehingga kesadaran politik juga rendah. Organisasi politik masyarakat sangat berpengaruh terhadap pendidikan politik karena dalam organisasi politik, sosial, dan organisasi masyarakat lainnya tentu menjadi pendukung terhadap kualitas individu maupun kelompok. Anggota masyarakat yang berpengalaman dalam berorganisai tentu memiliki pendidikan politik yang baik.

Kemudian faktor yang mempengaruhi pandangan masyarakat terhadap objek politik adalah sikap politik calon gubernur dan wakil gubernur. Kepercayaan politik masyarakat terhadap calon sangat mempengaruhi, dan adanya hubungan timbal balik politik. Dalam hal ini masyarakat masih beranggapan bahwa calon yang memberikan uang (money politik) itulah nantinya yang akan dipilih oleh mereka.

\section{SARAN}

Saran yang dapat penulis berikan kepada beberapa pihak antara lain:

1. Kepada KPU

Terkait pelaksanaan pemilihan gubernur dan wakil gubernur, KPU sebagai penyelenggara sudah melaksanakan tugas pokok dan fungsinya dengan baik. Sosialisasi yang dilakukan oleh KPU juga dinilai cukup baik karena pada tahun 2018 ini, sosialisasi sudah dilaksanakan dengan maksimal. Saran yang diberikan oleh peneliti terkait dengan penelitian ini adalah KPU seyogyanya melaksanakan sosialisasi secara lebih maksimal lagi sehingga masyarakat dapat mengetahui dan nantinya masyarakat memiliki kesadaran untuk datang ke TPS untuk melakukan pencoblosan baik itu pemilihan Presiden dan wakil presiden, DPR/DPRD, DPD, Gubernur, maupun pilkada di tingkat kabupaten.

\section{Kepada Masyarakat}

Saran yang dapat penulis sampaikan adalah sebaiknya masyarakat lebih mengetahui arti penting pemilu, karena hal pemilu adalah memilih wakilnya sendiri dan masyarakat seyogyanya sadar bahwa satu suara mereka sangat berharga untuk proses demokrasi.

\section{Kepada pada peneliti berikutnya}


Agar peneliti berikutnya dapat melakukan pendekatan kepada masyarakat khususnya masyarakat pedesaan sehingga msyarakat di tingkat bawah juga sadar akan pentingnya suara mereka di proses demokrasi.

\section{DAFTAR PUSTAKA}

\section{Buku-buku}

Almond, Gabriel A. Dan Sydney Verba. (1963). The Civic Culture: Political Attitudes And Democracy In Five Nation. Princeton University press: Princeton

Marijan, Kacung, (2003). Demokratisasi Di Daerah: Pelajaran Dari Pilkada Secara Langsung. Eurika. Surabaya

Marijan, Kacung, (2010). Sistem Politik Indonesia: Konsolidasi Demokrasi Pasca-Orde Baru. Prenada media. Jakarta

RPJMD Kabupaten Blora 2016-2021

\section{Jurnal}

Akbar, M. (2016). Partisipasi Politik Masyarakat Dalam Memilih Calon Bupati Gowa Pada Pilkada 2015 Kabupaten Gowa s k r i p s i.

Andriyus. (2013). Faktor-Faktor yang Mempengaruhi Partisipasi Politik Masyarakat pada Pemilihan Umum Legislatif 2009 di Keamatan Singingi Hilir Kabupaten Kuantan Singingi, 2(September).

Arianto, B. (2011). Analisis penyebab masyarakat tidak memilih dalam pemilu, 1(1), 51-60.

Darumurti, A., \& Sulaksono. (2014). Pemetaan Faktor Yang Mempengaruhi partisipasi pemilih di Kabupaten Bantul.

Hendrik, D. (2008). Variabel-variabel yang Mempengaruhi Rendahnnya Partisipasi Politik Masyarakat dalam Pilkada Walikota dan Wakil Walikota Padang Tahun 2008, 137-148.

Muslimat, A. (2008). Rendahnya Partisipasi Wanita Di Bidang Politik Ade Muslimat Universitas Serang Raya; Pusat Studi Wanita Provinsi Banten, 17-30. 
Nurhayati, S. (2011). Partisipasi politik masyarakat sedulur sikep desa karangrowo kecamatan undaan kabupaten kudus skripsi.

Octavia, G. (2015). Partisipasi Politik Masyarakat Kota Pekanabaru Pada Pemilihan Umum Kepala Daerah Tahun 2013, 2(1), 1-14.

Santi Lusiani, W. \& M. M. (2017). Partisipasi Politik Pada Penduduk Sirkuler Dalam Pemilihan Gubernur Jawa Tengah Tahun 2013, 2(1).

Suharyanto, A. (2014). Partisipasi Politik Masyarakat Tionghoa dalam Pemilihan Kepala Daerah, 2(2), 166-175.

Tyesta, L. (2019). Meningkatkan Demokrasi Konstitusional Di Indonesia ( Studi Terhadap Pelaksanaan Pilkada Serentak Di Provinsi Sulawesi Selatan Tahun 2015 )

\section{Data Internet}

https://pilkada.tempo.co/read/1063143/di-blora-sudirman-said-sebut-kartutani-itu-malah-bikin-susah/full\&view=ok

https://news.detik.com/berita-jawa-tengah/d-3953819/begini-janji-ganjaragar-pasar-di-blora-tak-lagi-tumpah-ke-jalan 